\title{
Screening for germline KCNQ1 and KCNE2 mutations in a set of somatotropinoma patients
}

\author{
Anna-Pauliina livonen', Johanna Känsäkoski' ${ }^{1}$ Atte Karppinen², Leena Kivipelto², Camilla Schalin-Jäntti ${ }^{3}$ \\ Auli Karhu ${ }^{4}$ and Taneli Raivio
}

${ }^{1}$ Institute of Biomedicine/Physiology, Biomedicum Helsinki, University of Helsinki, Helsinki, Finland

${ }^{2}$ Department of Neurosurgery, Helsinki University Hospital, Helsinki, Finland

${ }^{3}$ Department of Endocrinology, Abdominal Center, University of Helsinki and Helsinki University Hospital, Helsinki, Finland

${ }^{4}$ Department of Medical and Clinical Genetics, RPU, Biomedicum Helsinki, University of Helsinki, Helsinki, Finland

Correspondence should be addressed to A Karhu or T Raivio: auli.karhu@helsinki.fi or taneli.raivio@helsinki.fi

\begin{abstract}
Objective: Recently, mutations in KCNQ1, a potassium channel gene usually linked to long QT syndrome, were reported to cause maternally inherited gingival fibromatosis and growth hormone deficiency (GHD). Expression of the mutated KCNQ1 with the auxiliary potassium channel subunit KCNE2 was shown to reduce pituitary hormone secretion in functional experiments. Here, we investigated if germline mutations in KCNQ1 and KCNE2 were present in patients with somatotropinomas, which represent a model of growth hormone excess.

Design and methods: KCNQ1 and KCNE2 were screened for germline mutations in 53 patients with acromegaly by Sanger sequencing. Effects of the variants were predicted by in silico tools.

Results: Only deep intronic and synonymous polymorphisms were detected in KCNQ1. These findings were likely insignificant based on in silico predictions and the variants' frequencies in the general population. In KCNE2, a heterozygous c.22A>G, p.(Thr8Ala) mutation with unknown significance was found in three patients. It was present in the database controls with a frequency of 0.0038 .

Conclusions: KCNQ1 or KCNE2 mutations do not appear to account for somatotropinoma formation, although larger patient series are needed to validate the findings.
\end{abstract}

Endocrine Connections (2018) 7, 645-652

\section{Introduction}

Somatic growth and final height are the sum of multiple factors: nutritional status, general health, hormones, psychosocial well-being as well as inherited and epigenetic factors. Short or tall stature and body proportions also have huge social significance and they can predict adult life health and reproductive success $(1,2)$. Growth hormone $(\mathrm{GH})$, which is secreted from the anterior pituitary somatotroph cells, regulates human growth under the influence of hypothalamic inputs such as growth hormone-releasing hormone (GHRH) and somatostatin as well as several peripheral hormones.

GH-secreting pituitary adenomas, i.e. somatotropinomas, lead to acromegaly in adults and (acro-) gigantism in children and adolescents. Development of acromegaly is often insidious: most patients are diagnosed in their fifth decade of life with a median diagnostic delay of 4.5-5 years (3). Acromegaly patients have increased mortality compared to the general http://www.endocrineconnections.org https://doi.org/10.1530/EC-18-0123
C2018 The authors Published by Bioscientifica Ltd
This work is licensed under a Creative Commons Attribution-NonCommercial-NoDerivatives 4.0 International License. 
population $(4,5)$. Somatotropinomas are the third most common type (9-16.5\% of cases) of pituitary adenomas after prolactinomas and non-functioning adenomas (6). In approximately $5 \%$ of all pituitary adenoma cases, affected patients have a familial background, the vast majority of acromegaly-causing somatotropinomas being spontaneous (7). Somatotropinomas can present in familial tumor-causing syndromes or the predisposition to a pituitary adenoma can run in families without syndromic characteristics or even strong family history of the disease (7). However, in about half of the familial somatotropinoma cases, the possible underlying germline genetic defect cannot be identified, which implies that genes responsible for tumor formation remain undiscovered (8). Identification of new predisposing genes would enable earlier detection of pituitary adenomas and therefore improve clinical management of patients.

Recently, we showed that two missense mutations in KCNQ1 (potassium voltage-gated channel subfamily Q member 1), underlie maternally inherited gingival fibromatosis and autosomal dominant growth hormone deficiency which, in some patients, expanded to multiple pituitary hormone deficiency (9). Intriguingly, KCNQ1 was shown to be expressed in mouse hypothalamic GHRH neurons and somatotrophs (9), and in functional studies, co-expression of the mutant KCNQ1 protein with KCNE2 (potassium voltage-gated channel subfamily E regulatory subunit 2) lead to diminished hormone secretion from a mouse pituitary cell line (9). KCNE2 is an auxiliary subunit that is required for the formation of functional potassium channels with KCNQ1 in several secretory or excitable cells, for instance, in the stomach, thyroid and heart (10), and, as it seems, in the pituitary (9). Based on these findings, we hypothesized that germline mutations in these two genes could lead to an opposite phenotype, overproduction of $\mathrm{GH}$, and thereby predispose to somatotropinoma formation in some somatotropinoma patients.

\section{Subjects and methods}

We studied a set of 44 sporadic and one familial (patient 852, who had an affected sister) cases with GH-secreting pituitary adenomas. Moreover, whole-genome sequencing (WGS) data from eight patients with somatotropinomas were exploited. The tumors of these eight patients were Gsp mutation negative. The germline WGS data did not reveal mutations in known genes linked to inherited forms of pituitary adenoma (11). All patients had been

$$
\text { http://www.endocrineconnections.org }
$$

previously sequenced negative for AIP (aryl hydrocarbon receptor-interacting protein) and CDKN1B (cyclindependent kinase inhibitor 1B) (12) mutations as well as the GPR101 (G protein-coupled receptor 101) variant p.Glu308Asp.

Patient age at diagnosis ranged from 14 to 56 years with the mean age of 39 years (Table 1). One of the studied cases was a giant (ST10) and the rest had typical acromegaly phenotypes. All patients were operated in Finland. Forty-nine cases represented the Finnish population and four had non-Finnish origins: these patients were from Estonia, Spain, Italy and Tunis (Table 1). Informed consent was obtained from all patients, and in the case of minor/children, a parent or guardian gave the consent. The study was approved by the Ethics Committee of the Hospital district of Helsinki and Uusimaa, and it was conducted in accordance with the Declaration of Helsinki.

Peripheral blood samples were collected from the patients for DNA extraction. DNA was extracted from EDTA blood samples by a non-enzymatic procedure (13). The coding exons and exon-intron boundaries of KCNQ1 (ENSG00000053918, ENST00000155840.9, Ensembl release 90) and KCNE2 (ENSG00000159197, ENST00000290310.3) were then PCR amplified. The PCR conditions are available upon request and the primers are provided in Supplementary Table 1 (see section on supplementary data given at the end of this article). The PCR products were purified with ExoProStar treatment (GE Healthcare Life Sciences) and sequenced from the forward direction using the ABI BigDyeTerminator Cycle Sequencing Kit (v3.1) and ABI Prism 3730xl DNA Analyzer automated sequencer (Applied Biosystems). The DNA sequences were aligned and read with Sequencher 4.9 software (Gene Codes Corporation, Ann Arbor, MI, USA). In addition to the Sanger sequenced samples, KCNQ1 and KCNE2 were manually verified from the WGS normal blood-derived DNA. Both gene regions, including all the exons and intronic regions equivalent to the regions gained from the Sanger-sequenced amplicons, were analyzed.

Allele frequencies of the identified variants were validated from the Genome Aggregation Database (gnomAD) (http://gnomad.broadinstitute.org/) (14). This database contains WGS and exome data from 138,632 individuals including 12,897 Finnish samples. Effects of the identified variants on transcripts were predicted with Human Splicing Finder (http://www.umd.be/HSF3/) (15) and MutationTaster (http://www.mutationtaster.org/) (16) online tools. Additionally, we utilized the Polyphen-2 (Polymorphism Phenotyping v2; (http://genetics.bwh. harvard.edu/pph2/)) (17) and SIFT (http://sift.jcvi.org/) 
Table 1 Patient information and the variants detected in the coding regions of KCNQ1 and KCNE2. ORIGIN LISÄTTÄVÄ.

\begin{tabular}{|c|c|c|c|c|c|c|c|c|c|c|}
\hline Patient & Sex & $\begin{array}{l}\text { Age } \\
\text { at } \mathrm{Dg}\end{array}$ & $\begin{array}{l}\text { Age at } \\
\text { Op }\end{array}$ & Clinical Dg & KCNQ1 & & MAF $^{c}$ & KCNE2 & & MAF $^{c}$ \\
\hline 331 & M & 39 & & $\mathrm{GH}$ & - & & & - & & \\
\hline 332 & $\mathrm{~F}$ & & 39 & $\mathrm{GH}$ & $\begin{array}{l}\text { c. } 1986 C>T, \\
\text { p. }(\text { Tyr662=) }\end{array}$ & rs11601907 & 0.1748 & - & & \\
\hline 335 & M & 42 & 42 & $\mathrm{GH}$ & - & & & - & & \\
\hline 336 & $\mathrm{~F}$ & 25 & & $\mathrm{GH}$ & $\begin{array}{l}\text { c. } 1986 C>T, \\
\text { p. }(\text { Tyr662=) }\end{array}$ & rs11601907 & 0.1748 & - & & \\
\hline 337 & $\mathrm{~F}$ & 43 & 53 & $\mathrm{GH}$ & $\begin{array}{r}\text { c. } 1638 \mathrm{G}>\mathrm{A}^{\mathrm{b}}, \\
\text { p. }(\text { Ser546=) }\end{array}$ & rs1057128 & 0.2013 & - & & \\
\hline 338 & M & 38 & & $\mathrm{GH}$ & - & & & - & & \\
\hline 340 & M & 38 & 60 & $\mathrm{GH}$ & $\begin{array}{l}\text { c. } 1986 C>T, \\
\text { p. }(T y r 662=)\end{array}$ & rs11601907 & 0.1748 & - & & \\
\hline 341 & $\mathrm{~F}$ & 39 & & $\mathrm{GH}$ & - & & & - & & \\
\hline 343 & M & 42 & 42 & $\mathrm{GH}$ & $\begin{array}{l}\text { c. } 1986 C>T, \\
\text { p. }(\text { Tyr662=) }\end{array}$ & rs11601907 & 0.1748 & - & & \\
\hline 344 & M & 36 & & $\mathrm{GH}$ & $\begin{array}{l}\text { c. } 1986 C>T, \\
\text { p. }(\text { Tyr662=) }\end{array}$ & rs11601907 & 0.1748 & - & & \\
\hline 345 & M & 38 & & $\mathrm{GH}$ & $\begin{array}{l}\text { c. } 1986 C>T, \\
\text { p. }(\text { Tyr662=) }\end{array}$ & rs11601907 & 0.1748 & - & & \\
\hline 346 & M & 29 & & $\mathrm{GH}$ & - & & & $\begin{array}{l}\text { c. } 22 \mathrm{~A}>\mathrm{G}, \\
\text { p.(Thr8Ala) }\end{array}$ & rs2234916 & 0.0038 \\
\hline 347 & M & 30 & 34 & $\mathrm{GH}$ & $\begin{array}{l}\text { c. } 1986 C>T, \\
\text { p. }(\text { Tyr662=) }\end{array}$ & rs11601907 & 0.1748 & - & & \\
\hline 348 & $\mathrm{~F}$ & 42 & 42 & $\mathrm{GH}$ & - & & & - & & \\
\hline 349 & M & 38 & 40 & $\mathrm{GH}$ & $\begin{array}{l}\text { c. } 1986 C>T, \\
\text { p. }(\text { Tyr662=) }\end{array}$ & rs11601907 & 0.1748 & - & & \\
\hline 350 & $F$ & 36 & 36 & $\mathrm{GH}$ & - & & & - & & \\
\hline 351 & M & 40 & 40 & $\mathrm{GH}$ & - & & & - & & \\
\hline 352 & M & 33 & 33 & GH & $\begin{array}{l}\text { c. } 1986 C>T, \\
\text { p. }(\text { Tyr662=) }\end{array}$ & rs11601907 & 0.1748 & - & & \\
\hline 353 & $\mathrm{~F}$ & 38 & 39 & $\mathrm{GH}$ & $\begin{array}{l}\text { c. } 1986 C>T, \\
\text { p. }(\text { Tyr662=) }\end{array}$ & rs11601907 & 0.1748 & - & & \\
\hline 415 & $\mathrm{~F}$ & 39 & 45 & $\mathrm{GH}$ & $\begin{array}{l}\text { c. } 1638 G>A, \\
\text { p. }(\text { Ser546=) }\end{array}$ & rs1057128 & 0.2013 & - & & \\
\hline 416 & $\mathrm{~F}$ & 40 & 40 & $\mathrm{GH}$ & $\begin{array}{r}\text { c. } 1638 G>A^{b}, \\
\text { p. }(\text { Ser546=) }\end{array}$ & rs1057128 & 0.2013 & - & & \\
\hline 417 & $F$ & 42 & 43 & $\mathrm{GH}$ & $\begin{array}{l}\text { c. } 1986 C>T, \\
\text { p. }(\text { Tyr662 }=)\end{array}$ & rs11601907 & 0.1748 & - & & \\
\hline 418 & $F$ & 44 & 44 & $\mathrm{GH}$ & $\begin{array}{l}\text { c. } 1986 C>T, \\
\text { p. }(\text { Tyr662=) }\end{array}$ & rs11601907 & 0.1748 & - & & \\
\hline 419 & $\mathrm{~F}$ & 22 & 38 & $\mathrm{GH}$ & $\begin{array}{l}\text { c. } 1986 C>T, \\
\text { p. }(\text { Tyr662=) }\end{array}$ & rs11601907 & 0.1748 & - & & \\
\hline 420 & $\mathrm{~F}$ & 33 & 33 & $\mathrm{GH}$ & - & & & - & & \\
\hline 421 & M & 35 & & $\mathrm{GH}$ & - & & & - & & \\
\hline \multirow[t]{2}{*}{422} & $\mathrm{~F}$ & 32 & 47 & $\mathrm{GH}$ & $\begin{array}{l}\text { c. } 1986 C>T, \\
\text { p. }(\text { Tyr662=) }\end{array}$ & rs11601907 & 0.1748 & - & & \\
\hline & & & & & $\begin{array}{r}\text { c. } 1638 G>A^{b}, \\
\text { p. }(\text { Ser546=) }\end{array}$ & rs1057128 & 0.2013 & - & & \\
\hline 423 & M & 34 & 46 & $\mathrm{GH}$ & $\begin{array}{l}\text { c. } 1638 \mathrm{G}>\mathrm{A}, \\
\text { p.(Ser546=) }\end{array}$ & rs1057128 & 0.2013 & - & & \\
\hline 445 & $\mathrm{~F}$ & 39 & 39 & $\mathrm{GH}$ & $\begin{array}{l}\text { c. } 1986 C>T, \\
\text { p. }(\text { Tyr662=) }\end{array}$ & rs11601907 & 0.1748 & - & & \\
\hline 720 & $F$ & 36 & & $\mathrm{GH}$ & - & & & - & & \\
\hline 721 & M & 43 & & $\mathrm{GH}$ & - & & & - & & \\
\hline 725 & M & 40 & & $\mathrm{GH}$ & $\begin{array}{r}\text { c. } 1638 G>A^{b}, \\
\text { p. }(\text { Ser546=) }\end{array}$ & rs1057128 & 0.2013 & - & & \\
\hline 813 & $\mathrm{~F}$ & & 43 & $\mathrm{GH}$ & $\begin{array}{l}\text { c. } 1638 G>A, \\
\text { p. }(\text { Ser546=) }\end{array}$ & rs1057128 & 0.2013 & - & & \\
\hline 860 & $F$ & & 31 & $\mathrm{GH}$ & - & & & - & & \\
\hline
\end{tabular}


Table 1 Continued.

\begin{tabular}{|c|c|c|c|c|c|c|c|c|c|c|}
\hline Patient & Sex & $\begin{array}{l}\text { Age } \\
\text { at Dg }\end{array}$ & $\begin{array}{c}\text { Age at } \\
\text { Op }\end{array}$ & Clinical Dg & KCNQ1 & & MAF $^{c}$ & KCNE2 & & MAF $^{c}$ \\
\hline 861 & $\mathrm{M}$ & 47 & 47 & $\mathrm{GH}$ & - & & & $\begin{array}{l}\text { c. } 22 \mathrm{~A}>\mathrm{G}, \\
\text { p. }(\text { Thr8Ala })\end{array}$ & rs2234916 & 0.0038 \\
\hline 862 & $\mathrm{~F}$ & 53 & & GH/PRL & $\begin{array}{l}\text { c. } 1986 \mathrm{C}>\mathrm{T}, \\
\text { p. }(\text { Tyr662=) }\end{array}$ & rs11601907 & 0.1748 & - & & \\
\hline 833 & $M$ & & 44 & $\mathrm{GH}$ & $\begin{array}{c}\text { c. } 1638 G>A^{b} \\
\text { p. }(\text { Ser } 546=)\end{array}$ & rs1057128 & 0.2013 & - & & \\
\hline 842 & $M$ & & 60 & $\mathrm{GH}$ & $\begin{array}{l}\text { c. } 1986 \mathrm{C}>\mathrm{T}, \\
\text { p. }(\text { Tyr662=) }\end{array}$ & rs11601907 & 0.1748 & - & & \\
\hline 847 & $\mathrm{~F}$ & 26 & & $\mathrm{GH}$ & $\begin{array}{l}\text { c. } 1638 G>A, \\
\text { p. }(\text { Ser } 546=)\end{array}$ & rs1057128 & 0.2013 & - & & \\
\hline 848 & $\mathrm{~F}$ & 53 & & $\mathrm{GH}$ & $\begin{array}{l}\text { c. } 1986 C>T, \\
\text { p. }(\text { Tyr662=) }\end{array}$ & rs11601907 & 0.1748 & - & & \\
\hline 849 & $\mathrm{M}$ & 44 & 44 & $\mathrm{GH}$ & - & & & - & & \\
\hline $852^{d}(I)$ & $\mathrm{M}$ & 37 & 37 & $\mathrm{GH}$ & - & & & - & & \\
\hline 856 & $\mathrm{M}$ & 25 & & $\mathrm{GH}$ & - & & & - & & \\
\hline 857 & $\mathrm{M}$ & 41 & & GH/PRL & $\begin{array}{l}\text { c. } 1638 G>A, \\
\text { p. }(\operatorname{Ser} 546=)\end{array}$ & rs1057128 & 0.2013 & - & & \\
\hline 858 & $\mathrm{~F}$ & 33 & & $\mathrm{GH}$ & $\begin{array}{l}\text { c. } 1638 G>A, \\
\text { p. }(\text { Ser } 546=)\end{array}$ & rs1057128 & 0.2013 & - & & \\
\hline ST5 ${ }^{a}$ & $\mathrm{M}$ & 56 & & $\mathrm{GH}$ & $\begin{array}{l}\text { c. } 1986 C>T, \\
\text { p. }(\text { Tyr662=) }\end{array}$ & rs11601907 & 0.1748 & - & & \\
\hline $\mathrm{STG}^{\mathrm{a}}(\mathrm{T})$ & $\mathrm{M}$ & 40 & & $\mathrm{GH}$ & - & & & $\begin{array}{l}\text { c. } 22 \mathrm{~A}>\mathrm{G}, \\
\text { p. }(\text { Thr } 8 \mathrm{Ala})\end{array}$ & rs2234916 & 0.0038 \\
\hline $\mathrm{ST7}^{\mathrm{a}}(\mathrm{E})$ & $\mathrm{F}$ & 40 & & $\mathrm{GH}$ & $\begin{array}{l}\text { c. } 1638 G>A, \\
\text { p. }(\text { Ser } 546=)\end{array}$ & rs1057128 & 0.2013 & - & & \\
\hline ST ${ }^{a}$ & $\mathrm{~F}$ & 55 & & $\mathrm{GH}$ & - & & & - & & \\
\hline ST9a & $\mathrm{F}$ & 38 & & $\mathrm{GH}$ & $\begin{array}{l}\text { c. } 1638 G>A, \\
\text { p. }(\text { Ser } 546=)\end{array}$ & rs1057128 & 0.2013 & - & & \\
\hline $\mathrm{ST} 10^{\mathrm{a}, \mathrm{e}}$ & $\mathrm{M}$ & 14 & & $\mathrm{GH}$ & $\begin{array}{l}\text { c. } 1986 \mathrm{C}>\mathrm{T}, \\
\text { p. }(\text { Tyr662=) }\end{array}$ & rs11601907 & 0.1748 & - & & \\
\hline $\mathrm{ST} 11^{\mathrm{a}}$ & $\mathrm{F}$ & 24 & & $\mathrm{GH}$ & $\begin{array}{l}\text { c. } 1986 C>T, \\
\text { p. }(\text { Tyr662 }=)\end{array}$ & rs11601907 & 0.1748 & - & & \\
\hline $\mathrm{ST} 12^{\mathrm{a}}(\mathrm{S})$ & $\mathrm{M}$ & 37 & & $\mathrm{GH}$ & $\begin{array}{l}\text { c. } 1638 G>A, \\
\text { p. }(\text { Ser } 546=)\end{array}$ & rs1057128 & 0.2013 & - & & \\
\hline
\end{tabular}

aWhole genome sequencing data from Välimäki et al. 2015 (11); b Homozygous change; 'Minor allele frequency (MAF); control allele frequencies: http:// gnomad.broadinstitute.org/ (14); ${ }^{\mathrm{d}}$ Familial background; ${ }^{\mathrm{G}} \mathrm{Giant}$.

Dg, diagnosis; E, Estonian; GH, growth hormone; I, Italian; Op, operation; PRL, prolactin; S, Spanish; T, Tunisian.

(18) tools and the Clinvar database (https://www.ncbi. nlm.nih.gov/clinvar/) in the functional predictions of the c.22A>G, p.(Thr8Ala) missense mutation found in KCNE2. The significance of the allele frequency differences between the cases and database controls were calculated with Fisher's exact test by using $\mathrm{R}$ software. $P<0.05$ was accepted to indicate statistical significance.

\section{Results}

To evaluate if germline mutations in KCNQ1 and KCNE2 could increase susceptibility to somatotropinoma, we amplified and Sanger-sequenced all coding exons and exon-intron boundaries of these genes from the patient genomic DNA. KCNQ1 and KCNE2 were also screened for somatic mutations in the eight previously

$$
\begin{array}{lr}
\text { http://www.endocrineconnections.org } & \text { O2018 The authors } \\
\text { https://doi.org/10.1530/EC-18-0123 } & \text { Published by Bioscientifica Ltd }
\end{array}
$$

whole-genome sequenced samples. No somatic hits were detected. Effects of the found variants on gene function were predicted with several in silico tools, and the gnomAD database (14) was used as a variant frequency control set.

From the blood-derived DNA, we detected two synonymous coding variants in KCNQ1, c.1638G>A, p. $($ Ser546=) (rs1057128) and c.1986C $>$ T, p. $($ Tyr662=) (rs11601907). According to Human Splicing Finder and MutationTaster, these synonymous variants do not likely affect splicing. The c.1638G >A, p.(Ser546=) variant had a frequency of 0.2013 and the c.1986C>T, p.(Tyr662=) variant 0.1748 in the gnomAD database control population (Table 1). Taken together, the in silico predictions and frequencies in the general population suggest that these variants are benign. Moreover, both of the variants are silent that do not alter the amino acid sequence of

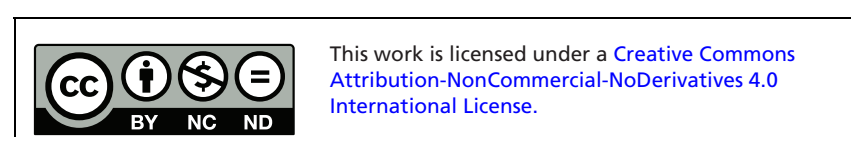


the protein. All other variants detected in KCNQ1 were located deep in introns (13 >bp from exon borders) and common in the gnomAD control population and/or were not predicted to affect splicing (Supplementary Table 2).

In three patients, one heterozygous missense variant in KCNE2, c.22A>G, p.(Thr8Ala) (rs2234916), was detected with an allele frequency of 0.028 among the patients. The frequency of this variant was 0.0038 in the gnomAD database, in which it was detected in a homozygous state in eight individuals. Among the Finnish controls $(12,897$ individuals), the variant frequency was 0.0038 as well. A significant difference in the allele frequencies between the patients and controls was found (OR, 7.73: 95\% CI, 1.56-23.32: $P=0.008$ ). This variant was disease causing according to MutationTaster, deleterious according to SIFT (score 0) and probably damaging according to PolyPhen-2 (score, 0.991). To evaluate allelic imbalance at the chromosomal region of c. $22 \mathrm{~A}>\mathrm{G}$, p.(Thr8Ala), we explored the WGS data of patient ST6. The sequences were obtained from the normal blood-derived DNA and the respective tumor tissue (11). Somatic copy-number profiling did not reveal allele gain or loss at the locus (Fig. 1).

\section{Discussion}

Endocrine pituitary cells express numerous voltagegated sodium, calcium, potassium and chloride ion channels (19). Ionic mechanisms play an essential role in the regulation of hormone secretion in pituitary cells,

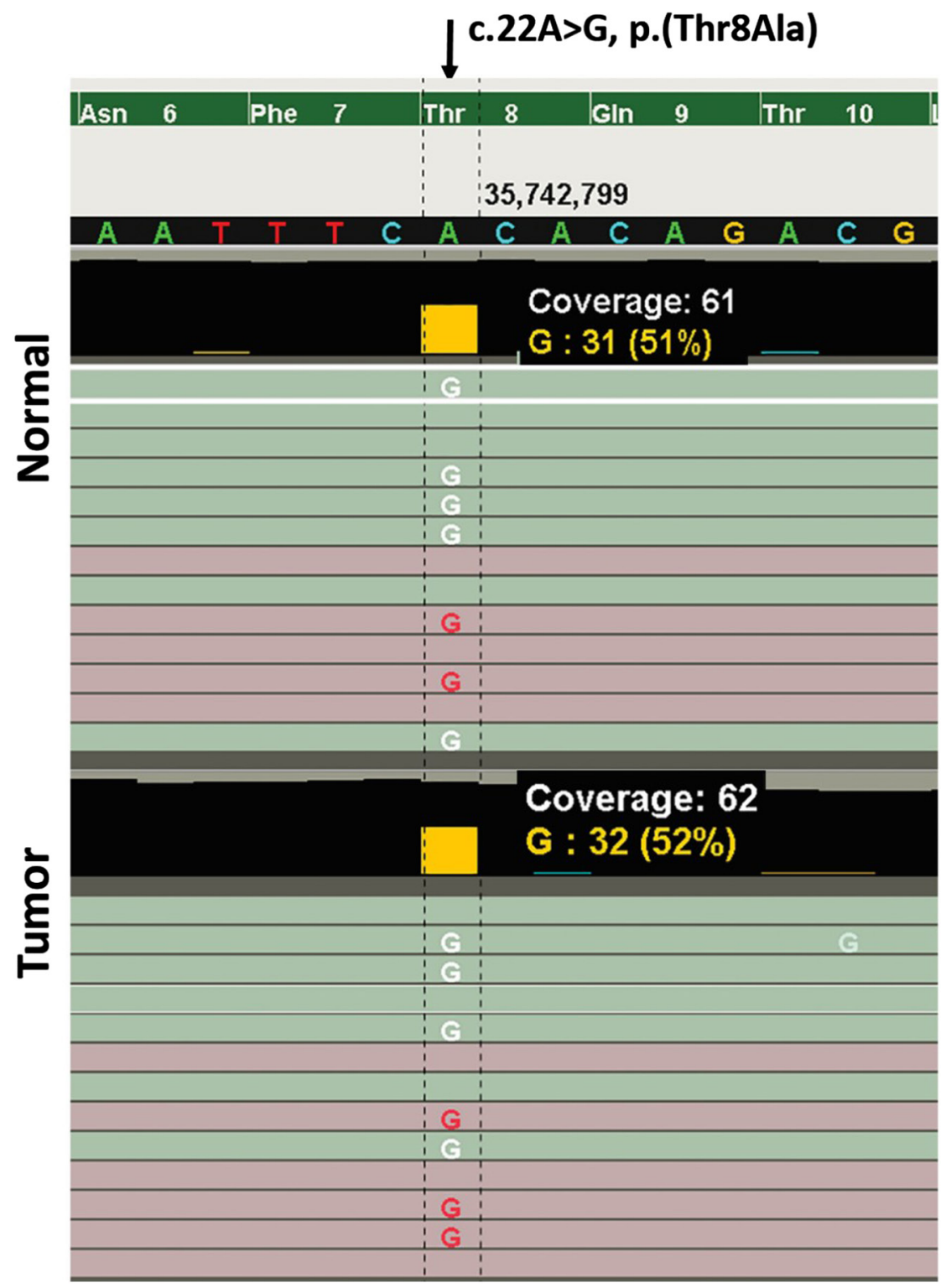

Figure 1

Whole-genome sequence reads of patient ST6 showing a heterozygous c.22A>G KCNE2 variant in DNA extracted from peripheral blood leukocytes and respective tumor tissue. Both blood and tumor tissues show close to $50-50 \%$ allele fraction. Only representative portion of the reads is seen in the figure. Coverage: number of total reads (61 reads cover the position), G: number of reads containing the $\mathrm{G}$ allele $(51 \%$ and $52 \%$ ). Red read: + direction, green read: - direction. An in-house tool BasePlayer (https:// doi.org/10.1101/126482) was used for the variant analysis.

http://www.endocrineconnections.org https://doi.org/10.1530/EC-18-0123
@2018 The authors Published by Bioscientifica Ltd
This work is licensed under a Creative Commons Attribution-NonCommercial-NoDerivatives 4.0 International License. 
such as GH-secreting somatotrophs. The status of electrical signaling in the pituitary cells is dependent on the release of stimulating and inhibiting neurohormones from the hypothalamus (19). These neurohormones act by stimulating and inhibiting $\mathrm{G}$ protein-coupled receptors

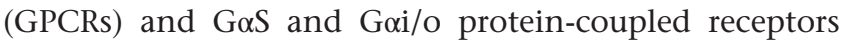
$(19,20,21)$. Both $G \alpha S$ and Goi signaling are known to be essential factors in the formation of somatotropinomas via cyclic adenosine monophosphate (cAMP) synthesis (21). cAMP is a mitogenic factor in somatotrophs, and increase in the intracellular cAMP concentration leads to the activation of protein kinase A (PKA) as well as further mitogenic signaling in GH-secreting somatotrophs (19, 20, 21).

Potassium channel genes can also be implicated in tumorigenesis, including angiogenesis, tumor invasion and growth (22). For example, recent findings suggest that KCNQ1 is a key regulator and a target gene in the Wnt/ $\beta$-catenin signaling pathway (23), which is implicated in pituitary development and tumorigenesis of craniopharyngiomas (24). Rapetti-Mauss et al. (23) showed that KCNQ1 suppresses the Wnt/ $\beta$-catenin signaling pathway and forms complexes with $\beta$-catenin and E-cadherin in the cell membrane. High expression of KCNQ1 was associated with high expression of E-cadherin. When KCNQ1 was suppressed, E-cadherin and $\beta$-catenin moved to the cytosol from the membrane, which was associated with proliferation of colorectal cancer cells and epithelial-to-mesenchymal transition (EMT) (23).

KCNQ1 is present in the somatotrope cell membrane (9), and E-cadherin is expressed in somatotropinomas (25). In a study by Fougner and colleagues, downregulation and redistribution of E-cadherin were associated with large tumors and partly to tumor invasiveness: Specifically, translocation of E-cadherin to the nucleus and subsequent loss of its membranous expression was demonstrated in a subset of exceptionally large, somatostatin analog (SMS)resistant somatotropinomas (25). Wnt pathway inhibitors have been found to be downregulated in GH-secreting pituitary tumors $(26,27)$, suggesting that Wnt signaling, possibly including KCNQ1 and E-cadherin, may participate in somatotropinoma formation.

In our patient set, we did not find any potentially pathogenic KCNQ1 changes. Two identified variants were synonymous substitutions and common in controls. In addition to KCNQ1, we screened the coding region of KCNE2 in our acromegaly patients. KCNE2 forms complexes with KCNQ1 in gastric parietal cells (28), it participates in the proliferation and activity of gastric secretory epithelial cells and its downregulated expression is implicated in gastric cancer $(29,30)$. In the present study, three patients carried the heterozygous c.22A>G, p.(Thr8Ala) (rs2234916) missense variant, which was the only KCNE2 variant found in our patient series. The allele frequency of this variant in the patient group was significantly higher compared to the general population $(P=0.008)$. Intriguingly, this finding suggests an association of the c. $22 \mathrm{~A}>\mathrm{G}$, p.(Thr8Ala) variant with acromegaly. In past publications, the c. $22 \mathrm{~A}>\mathrm{G}$, p.(Thr8Ala) variant has been described as potentially increasing the risk of congenital or acquired long QT syndrome and drug-induced cardiac arrhythmia, and it has been found in both healthy individuals and affected patients (31, 32, $33,34,35,36,37,38)$.

Anatomical pathology diagnosis revealed that all three tumors with the p.(Thr8Ala) variant were typical acidophilic GH-secreting adenomas without significant atypia. Tumors of 861 and ST6 showed low proliferation rates (Ki-67 1-2\%) and were p53 negative. No Ki-67 and p53 immunostaining were performed for the third tumor. Available electrocardiograms (ECG) showed that patient 861 had a normal QT interval. Patient ST6 had a prolonged QT interval during transient diabetic ketoacidosis (DKA). Prolonged QT interval occurs frequently during DKA $(39,40,41)$. In the case of our patient, the QT interval returned to normal after recovery and was normal in all subsequent ECGs.

We have recently identified KCNQ1, a gene previously implicated in cardiac arrhythmia syndromes, as a new factor associated with human growth and the anterior pituitary function (9). In the current study, we identified two coding KCNQ1 and one KCNE2 germline variants in somatotropinoma patients. While the definite exclusion of the pathogenic role of genetic variants is often challenging, our observations suggest that these variants are not associated with somatotropinoma tumorigenesis. However, our patient cohort was limited in size. Therefore, additional germline and/or somatic mutation screenings in larger patient cohorts with early onset and familial cases are needed, and the expression of KCNQ1 and KCNE2 in tumor tissues might be worth investigating. Especially the possible association of the KCNE2 c.22A>G, p.(Thr8Ala) variant with acromegaly requires further studies.

\section{Supplementary data}

This is linked to the online version of the paper at https://doi.org/10.1530/ EC-18-0123. 
Declaration of interest

The authors declare that there is no conflict of interest that could be perceived as prejudicing the impartiality of the research reported.

\section{Funding}

This work was supported by grants from the Academy of Finland (Finnish Center of Excellence Program 2012-2017) and Finnish Cancer Society.

\section{Acknowledgements}

The authors thank Dr Heikki Swan for ECG interpretations.

\section{References}

1 Batty GD, Shipley MJ, Gunnell D, Huxley R, Kivimäki M, Woodward M, Lee CM \& Smith GD. Height, wealth, and health: an overview with new data from three longitudinal studies. Economics and Human Biology 20097 137-152. (https://doi.org/10.1016/j. ehb.2009.06.004)

2 Pisanski K \& Feinberg D. Cross-cultural variation in mate preferences for averageness, symmetry, body size, and masculinity. Cross-Cultural Research 201347 162-197. (https://doi. org/10.1177/1069397112471806)

3 Lavrentaki A, Paluzzi A, Wass J \& Karavitaki N. Epidemiology of acromegaly: review of population studies. Pituitary 201720 4-9. (https://doi.org/10.1007/s11102-016-0754-x)

4 Dekkers OM, Biermasz NR, Pereira AM, Romijn JA \& Vandenbroucke JP. Mortality in acromegaly: a meta-analysis. Journal of Clinical Endocrinology and Metabolism 2008 9361-9367. (https://doi. org/10.1210/jc.2007-1191)

5 Ritvonen E, Löyttyniemi E, Jaatinen P, Ebeling T, Moilanen L, Nuutila P, Kauppinen-Mäkelin R \& Schalin-Jäntti C. Mortality in acromegaly: a 20-year follow-up study. Endocrine-Related Cancer 2016 23 469-480. (https://doi.org/10.1530/ERC-16-0106)

6 Marques P \& Korbonits M. Genetic aspects of pituitary adenomas. Endocrinology and Metabolism Clinics of North America 201746 335-374. (https://doi.org/10.1016/j.ecl.2017.01.004)

7 Beckers A, Aaltonen LA, Daly AF \& Karhu A. Familial isolated pituitary adenomas (FIPA) and the pituitary adenoma predisposition due to mutations in the aryl hydrocarbon receptor interacting protein (AIP) gene. Endocrine Reviews 201334 239-277. (https://doi. org/10.1210/er.2012-1013)

8 Rostomyan L, Daly AF, Petrossians P, Nachev E, Lila AR, Lecoq AL, Lecumberri B, Trivellin G, Salvatori R, Moraitis AG, et al. Clinical and genetic characterization of pituitary gigantism: an international collaborative study in 208 patients. Endocrine-Related Cancer 201522 745-757. (https://doi.org/10.1038/s41467-017-01429-z)

9 Tommiska J, Känsäkoski J, Skibsbye L, Vaaralahti K, Liu X, Lodge EJ, Tang C, Yuan L, Fagerholm R, Kanters JK, et al. Two missense mutations in KCNQ1 cause pituitary hormone deficiency and maternally inherited gingival fibromatosis. Nature Communications 20178 1289. (https://doi.org/10.1038/s41467-017-01429-z)

10 Abbott G. The KCNE2 K+ channel regulatory subunit: ubiquitous influence, complex pathobiology. Gene 2015569 162-172. (https:// doi.org/10.1016/j.gene.2015.06.061)

11 Välimäki N, Demir H, Pitkänen E, Kaasinen E, Karppinen A, Kivipelto L, Schalin-Jäntti C, Aaltonen LA \& Karhu A. Whole-genome sequencing of growth hormone (GH)-secreting pituitary adenomas. Journal of Clinical Endocrinology and Metabolism 2015100 3918-3927. (https://doi.org/10.1210/jc.2015-3129)

12 Georgitsi M, Raitila A, Karhu A, van der Luijt RB, Aalfs CM, Sane T, Vierimaa O, Mäkinen MJ, Tuppurainen K, Paschke R, et al. Germline
CDKN1B/p27Kip1 mutation in multiple endocrine neoplasia. Journal of Clinical Endocrinology and Metabolism 200792 3321-3325. (https:// doi.org/10.1210/jc.2006-2843)

13 Lahiri DK \& Nurnberger JI Jr. A rapid non-enzymatic method for the preparation of HMW DNA from blood for RFLP studies. Nucleic Acids Research 199119 5444. (https://doi.org/10.1093/nar/19.19.5444)

14 Lek M, Karczewski KJ, Minikel EV, Samocha KE, Banks E, Fennell T, O'Donnell-Luria AH, Ware JS, Hill AJ, Cummings BB, et al. Analysis of protein-coding genetic variation in 60,706 humans. Nature 2016 536 285-291. (https://doi.org/10.1038/nature19057)

15 Desmet FO, Hamroun D, Lalande M, Collod-Beroud G, Claustres \& Beroud C. Human Splicing Finder: an online bioinformatics tool to predict splicing signals. Nucleic Acids Research 200937 e67. (https:// doi.org/10.1093/nar/gkp215)

16 Schwarz JM, Cooper DN, Schuelke M \& Seelow D. MutationTaster2: mutation prediction for the deep-sequencing age. Nature Methods 201411 361-362. (https://doi.org/10.1038/nmeth.2890)

17 Adzhubei IA, Schmidt S, Peshkin L, Ramensky VE, Gerasimova A Bork P, Kondrashov AS \& Sunyaev SR. A method and server for predicting damaging missense mutations. Nature Methods 20107 248-249. (https://doi.org/10.1038/nmeth0410-248)

18 Kumar P, Henikoff S \& Ng PC. Predicting the effects of coding nonsynonymous variants on protein function using the SIFT algorithm. Nature Protocols 20094 1073-1081. (https://doi.org/10.1038/ nprot.2009.86)

19 Stojilkovic SS, Tabak J \& Bertram R. Ion channels and signaling in the pituitary gland. Endocrine Reviews 201031 845-915. (https://doi. org/10.1210/er.2010-0005)

20 Vallar L, Spada A \& Giannattasio G. Altered Gs and adenylate cyclase activity in human GH-secreting pituitary adenomas. Nature 1987330 566-568. (https://doi.org/10.1038/330566a0)

21 Tuominen I, Heliövaara E, Raitila A, Rautiainen MR, Mehine M, Katainen R, Donner I, Aittomäki V, Lehtonen HJ, Ahlsten M, et al. AIP inactivation leads to pituitary tumorigenesis through defective Gai-cAMP signaling. Oncogene 201534 1174-1184. (https://doi. org/10.1038/onc.2014.50)

22 Pardo LA \& Stühmer W. The roles of $\mathrm{K}(+)$ channels in cancer. Nature Reviews Cancer 201414 39-48. (https://doi.org/10.1038/nrc3635)

23 Rapetti-Mauss R, Bustos V, Thomas W, McBryan J, Harvey H, Lajczak N, Madden S, Pellissier B, Borgese F, Soriani O, et al. Bidirectional KCNQ1: $\beta$-catenin interaction drives colorectal cancer cell differentiation. PNAS 2017114 4159-4164. (https://doi. org/10.1073/pnas.1702913114)

24 Gaston-Massuet C, Andoniadou CL, Signore M, Jayakody SA, Charolidi N, Kyeyune R, Vernay B, Jacques TS, Taketo MM, Le Tissier $\mathrm{P}$, et al. Increased Wingless (Wnt) signaling in pituitary progenitor/stem cells gives rise to pituitary tumors in mice and humans. PNAS 2011108 11482-11487. (https://doi.org/10.1073/ pnas.1101553108)

25 Fougner SL, Lekva T, Borota OC, Hald JK, Bollerslev J \& Berg JP. The expression of E-cadherin in somatotroph pituitary adenomas is related to tumor size, invasiveness, and somatostatin analog response. Journal of Clinical Endocrinology and Metabolism 201095 2334-2342. (https://doi.org/10.1210/jc.2009-2197)

26 Elston MS, Gill AJ, Conaglen JV, Clarkson A, Shaw JM, Law AJ, Cook RJ, Little NS, Clifton-Bligh RJ, Robinson BG, et al. Wnt pathway inhibitors are strongly down-regulated in pituitary tumors. Endocrinology 2008149 1235-1242. (https://doi.org/10.1210/ en.2007-0542)

27 Elston MS \& Clifton-Bligh RJ. Identification of Wnt family inhibitors: a pituitary tumor directed whole genome approach. Molecular and Cellular Endocrinology 2010326 48-54. (https://doi.org/10.1016/j. mce.2010.02.039)

28 Abbott GW \& Roepke TK. KCNE2 and gastric cancer: bench to bedside. Oncotarget 20167 17286-17287. (https://doi.org/10.18632/ oncotarget.7921) 
29 Roepke TK, Anantharam A, Kirchhoff P, Busque SM, Young JB, Geibel JP, Lerner DJ \& Abbott GW. The KCNE2 potassium channel ancillary subunit is essential for gastric acid secretion. Journal of Biological Chemistry 2006281 23740-23747. (https://doi. org/10.1074/jbc.M604155200)

30 Roepke TK, Purtell K, King EC, La Perle KM, Lerner DJ \& Abbott GW. Targeted deletion of Kcne2 causes gastritis cystica profunda and gastric neoplasia. PLoS ONE 20105 e11451. (https://doi.org/10.1371/ journal.pone.0011451)

31 Sesti F, Abbott GW, Wei J, Murray KT, Saksena S, Schwartz PJ, Priori SG, Roden DM, George AL Jr \& Goldstein SA. A common polymorphism associated with antibiotic-induced cardiac arrhythmia. PNAS 200097 10613-10618. (https://doi.org/10.1073/pnas.180223197)

32 Larsen LA, Andersen PS, Kanters J, Svendsen IH, Jacobsen JR, Vuust J, Wettrell G, Tranebjaerg L, Bathen J \& Christiansen M. Screening for mutations and polymorphisms in the genes KCNH2 and KCNE2 encoding the cardiac HERG/MiRP1 ion channel: implications for acquired and congenital long-QT syndrome. Clinical Chemistry 2001 47 1390-1395.

33 Jongbloed R, Marcelis C, Velter C, Doevendans P, Geraedts J \& Smeets H. DHPLC analysis of potassium ion channel genes in congenital long QT syndrome. Human Mutation 200220 382-391. (https://doi.org/10.1002/humu.10131)

34 Ackerman MJ, Tester DJ, Jones GS, Will ML, Burrow CR \& Curran ME. Ethnic differences in cardiac potassium channel variants: implications for genetic susceptibility to sudden cardiac death and genetic testing for congenital long QT syndrome. Mayo Clinic Proceedings 200378 1479-1487. (https://doi.org/10.4065/78.12.1479)

35 Paulussen AD, Gilissen RA, Armstrong M, Doevendans PA, Verhasselt P, Smeets HJ, Schulze-Bahr E, Haverkamp W, Breithardt G,
Cohen N, et al. Genetic variations of KCNQ1, KCNH2, SCN5A, KCNE1, and KCNE2 in drug-induced long QT syndrome patients. Journal of Molecular Medicine 200482 182-188. (https://doi. org/10.1007/s00109-003-0522-z)

36 Aydin A, Bähring S, Dahm S, Guenther UP, Uhlmann R, Busjahn A \& Luft FC. Single nucleotide polymorphism map of five long-QT genes. Journal of Molecular Medicine 200583 159-165. (https://doi. org/10.1007/s00109-004-0595-3)

37 Mank-Seymour AR, Richmond JL, Wood LS, Reynolds JM, Fan YT, Warnes GR, Milos PM \& Thompson JF. Association of torsades de pointes with novel and known single nucleotide polymorphisms in long QT syndrome genes. American Heart Journal $2006 \mathbf{1 5 2}$ 1116-1122. (https://doi.org/10.1016/j.ahj.2006.08.020)

38 Arnestad M, Crotti L, Rognum TO, Insolia R, Pedrazzini M, Ferrandi C, Vege A, Wang DW, Rhodes TE, George AL Jr, et al. Prevalence of long-QT syndrome gene variants in sudden infant death syndrome. Circulation 2007115 361-367. (https://doi. org/10.1161/CIRCULATIONAHA.106.658021)

39 Youssef OI \& Farid SM. QTc and QTd in children with type 1 diabetes mellitus during diabetic ketoacidosis. ISRN Pediatrics 20122012 619107. (https://doi.org/10.5402/2012/619107)

40 Kuppermann N, Park J, Glatter K, Marcin JP \& Glaser NS. Prolonged QT interval corrected for heart rate during diabetic ketoacidosis in children. Archives of Pediatric and Adolescent Medicine 2008162 544-549. (https://doi.org/10.1001/archpedi.162.6.544)

41 Talebi S, Ghobadi F, Cacacho A, Olatunde O, DeRobertis A, Pekler G, Visco F, Mushiyev S \& Hassen GW. Looking at diabetic ketoacidosis through electrocardiogram window! American Journal of Emergency Medicine 201634 263-265. (https://doi.org/10.1016/j. ajem.2015.10.032)

Received in final form 21 March 2018

Accepted 9 April 2018 http://www.endocrineconnections.org https://doi.org/10.1530/EC-18-0123
()2018 The authors Published by Bioscientifica Ltd
This work is licensed under a Creative Commons Attribution-NonCommercial-NoDerivatives 4.0 International License. 